\title{
Synthesis of Rearranged Unsaturated Drimane Derivatives
}

\section{Domingos S. de Miranda ${ }^{a}$, Gelson J. A. da Conceição ${ }^{b}$, Julio Zukerman-Schpector ${ }^{c}$, Mário C. Guerrero ${ }^{b}$, Ulf Schuchardt ${ }^{b}$, Angelo C. Pinto ${ }^{d}$, Claudia M. Rezende ${ }^{d}$ and Anita J. Marsaioli ${ }^{b *}$}

\author{
${ }^{a}$ Instituto de Química, Universidade Federal de Uberlândia, CP 593, 38400-902, Uberlândia - MG, Brazil \\ ${ }^{\mathrm{b}}$ Instituto de Química, Universidade Estadual de Campinas, CP 6154, 13083-970, Campinas - SP, Brazil, \\ ${ }^{c}$ Departamento de Química, Universidade Federal de São Carlos, CP 676, 13565-905, São Carlos - SP, Brazil \\ ${ }^{\mathrm{d}}$ Instituto de Química, Universidade Federal do Rio de Janeiro, Ilha do Fundão, 21949-970, Rio de Janeiro - RJ, Brazil
}

\begin{abstract}
O presente trabalho relata a preparação e aplicação de três vinilcicloexenos devidamente funcionalizados (2,2-dimetil-3-vinilcicloex-3-en-1-ol, 2,2-dimetil-3-vinilcicloex-3-en-1-ona e 3,3dimetil-2-vinilcicloexeno) em reações de Diels-Alder com ésteres $\alpha, \beta$-insaturados (tiglato de metila e angelato de metila). Esta abordagem levou à síntese racêmica de dez octalinas possuindo esqueleto drimânico rearranjado (4 diastereoisômeros do 1-metoxicarbonil-6-hidroxi-1,2,5,5-tetrametil1,2,3,5,6,7,8,8a-octaidronaftaleno; 1-metoxicarbonil-6-oxo-1,2,5,5-tetrametil-1,2,3,4,5,6,7,8ocataidronaftaleno; 2-metoxicarbonil-6-oxo-1,2,5,5-tetrametil-1,2,3,5,6,7, 8,8a-octaidronaftaleno; 3 diastereoisômeros do 1-metoxicarbonil-1,2,5,5-tetrametil-1,2,3,5,6,7,8,8a-octaidronaftaleno e 2-metoxicarbonil-1,2,5,5-tetrametil-1,2,3,5,6,7,8,8a-octaidronaftaleno). Para a preparação dos dienos, utilizou-se a reação de acoplamento catalisada por paládio (reação de Stille) entre enoltriflatos (preparados pelo protocolo de Stang) e tri- $n$-butilvinilestanana. A estereoquímica relativa dos produtos foi estabelecida a partir de métodos espectroscópicos e análise de difração de raios-X de alguns dos derivados. Estes dados podem servir para a identificação de novos produtos naturais e corrigir algumas estruturas da literatura.
\end{abstract}

A full account to the preparation and application of three appropriately substituted vinylcyclohexenes (2,2-dimethyl-3-vinylcyclohex-3-en-1-ol, 2,2-dimethyl-3-vinylcyclohex-3-en1 -one and 3,3-dimethyl-2-vinylcyclohexene) in thermal Diels-Alder reactions with $\alpha, \beta$-unsaturated esters (methyl tiglate and methyl angelate) is given. This approach delivered the racemic synthesis of ten octalin derivatives bearing a rearranged drimane skeleton (4 diastereomers of 1 methoxycarbonyl-6-hydroxy-1,2,5,5-tetramethyl-1,2,3,5,6,7, 8,8a-octahydronaphthalene; 1 methoxycarbonyl-6-oxo-1,2,5,5-tetramethyl-1,2,3,4,5,6,7,8-octahydronaphthalene; 2methoxycarbonyl-6-oxo-1,2,5,5-tetramethyl-1,2,3,5,6,7,8,8a-octahydronaphthalene; 3 diastereomers of 1-methoxycarbonyl-1,2,5,5-tetramethyl-1,2,3,5,6,7,8,8a-octahydronaphthalene and 2-methoxycarbonyl-1,2,5,5-tetramethyl-1,2,3,5,6,7,8,8a-octahydronaphthalene). Central synthetic features included preparation of enoltriflates by Stang's protocol and the successful palladium-catalyzed cross-coupling reaction (Stille reaction) of the triflate with the tri- $n$ butylvinylstannane. The octalins relative stereochemistry was unequivocally ascertained by spectroscopic methods and/or X-ray crystallography and these data now stand as useful tools to support the correct assignment of related natural products usually isolated in minute amounts.

Keywords: Diels-Alder reaction, vinylcyclohexenes, rearranged drimane derivatives

\section{Introduction}

Nature is and will always be the most efficient and talented source of inspiration to the leading structures in synthesis and industry. Therefore, we focused on the

\footnotetext{
* e-mail: anita@iqm.unicamp.br
}

synthetic methodologies connected to a restricted group of natural products, i.e. partially-rearranged bicyclic terpenoids, among them, isopolyalthenol (1) and neopolyalthenol (2) (from Polyalthia suaveolens) ${ }^{1}$, mamanuthaquinone (from Faciospongia sp.) $)^{2}$ (3), dysidiolide (4) (from Dysidea etheria de Laubenfels) $)^{3}$, tetranor-halimanoic acid (5) (from Vellozia flavicans) ${ }^{4}$ and 


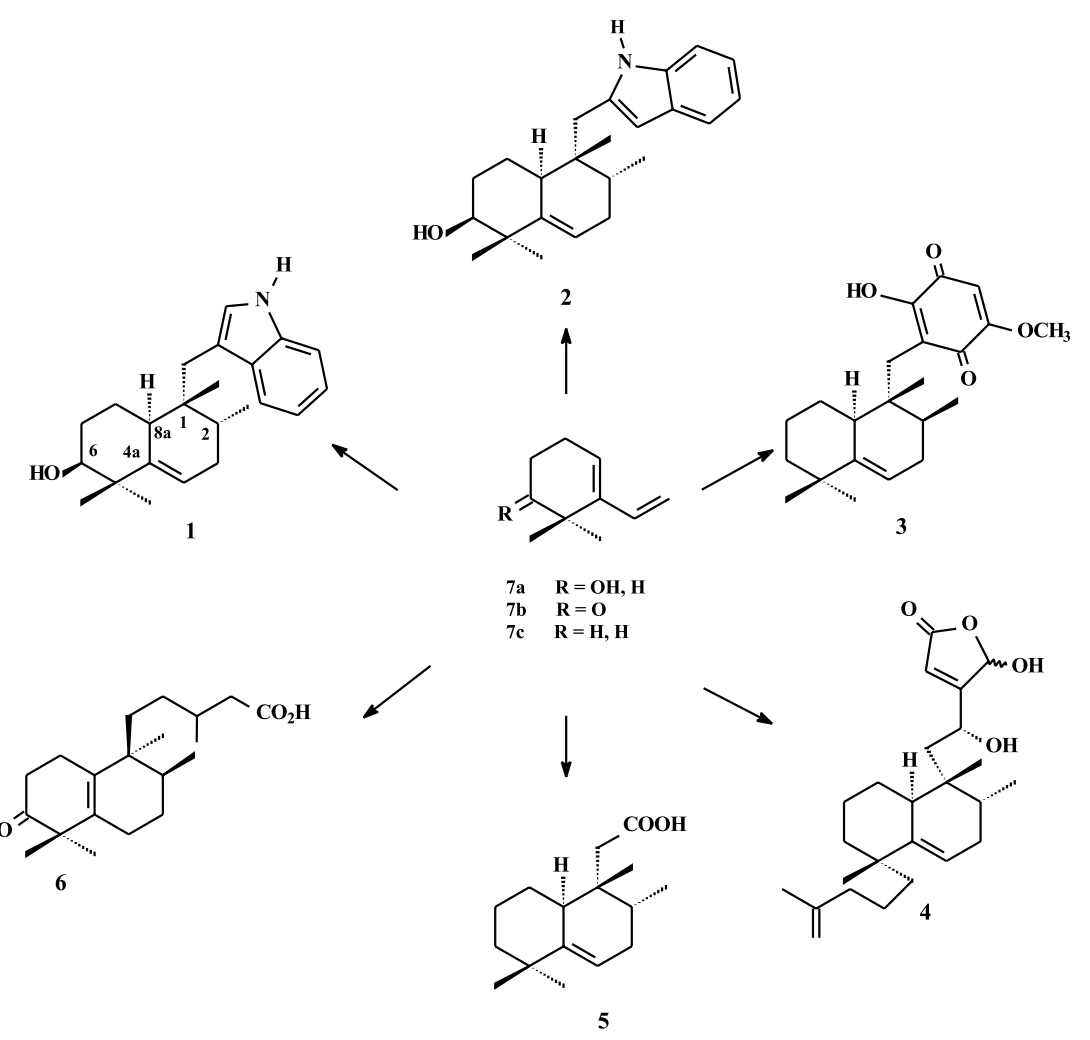

Scheme 1. Vinylcyclohexene derivatives: pivotal intermediates in the synthesis of relevant natural products through Diels-Alder reaction.

salmantic acid 6 (from Cistus laurifolius) ${ }^{5}$, as shown in Scheme 1.

The convergent construction of the octalin framework, with different side-chains at C-1 and an occasional oxo or hydroxy group at position 6, was envisioned by a DielsAlder (DA) reaction over vinylcyclohexenes of general type 7 (Scheme 1). This synthetic approach was proved unique in the synthesis of compounds $3^{6}$ and $4^{7}$. Moreover unambiguous identification of secondary metabolites occurring in minute amount is often a difficult task which can be minimized with the support of fully characterized model compounds. Herein we describe the cycloaddition of dienes ( \pm )-7a, $7 \mathbf{b}$ and $\mathbf{7 c}$ with methyl tiglate (methyl $E$ 2-methylbut-2-enoate) and methyl angelate (methyl Z-2methylbut-2-enoate) with a detailed spectroscopic characterization of the several adducts.

\section{Results and Discussion}

Kakisawa's ${ }^{8}$, Ley's $^{9}$ (modified by Mori ${ }^{10}$ ) and Knapp's ${ }^{11}$ methodologies are classic protocols to prepare vinylcyclohexene-type dienes, like $( \pm)-\mathbf{7 a}, \mathbf{7 b}$ and $\mathbf{7 c}$. Knapp's approach to functionalize cyclohexanones seemed particularly attractive as the use of vinylmagnesium bromide, instead of sodium acetylide, avoids the use of the cumbersome liquid ammonia required in some of the above-mentioned protocols.

The synthesis of $( \pm)-7 \mathbf{a}$ and $\mathbf{7 b}$ started from 2,2dimethylcyclohexane-1,3-dione $\mathbf{8 a}$, readily available in one step (ca. 82\% yield) from 2-methylcyclohexane-1,3-dione, $\mathrm{MeI}$ and $t$-BuOK/t-BuOH (Scheme 2). Triton B was reported $^{12}$ as an efficient base to perform this alkylation step but, in our hands, this condition failed to produce 8a in good yield. Access to diene ( \pm )-7a (route $\mathbf{A}$, Scheme 2 ) was gained with a selective reduction of one carbonyl of 8a with $\mathrm{NaBH}_{4}$ in methanol at $10{ }^{\circ} \mathrm{C}$, protection of the resulting alcohol with TBDMSCl, followed by vinyl Grignard reagent addition (Imamoto's ${ }^{13}$ approach) to the remaining carbonyl of ketone ( \pm )-9 complexed with $\mathrm{CeCl}_{3}$ and dehydration of the resulting allylic alcohol with $\mathrm{CuSO}_{4}$ (supported on silica gel) $)^{14}$ to furnish the the diene ( \pm )-10. Attempts to perform the direct addition of the Grignard reagent to the substrate were unsuccessful, an evidence that $( \pm)-9$ is an easily enolizable ketone.

Ensuing desilylation of ( \pm )-10 afforded the desired vinylcyclohexene ( \pm )-7a in five steps and $18 \%$ overall yield. However, the unsatisfactory results obtained from route $\mathbf{A}$ prompted us to switch to an alternative method (route $\mathbf{B}$, Scheme 2). Thus, ( \pm )-7a was synthesized according to the directives given by Snyder et al. ${ }^{15}$ in the synthesis of 


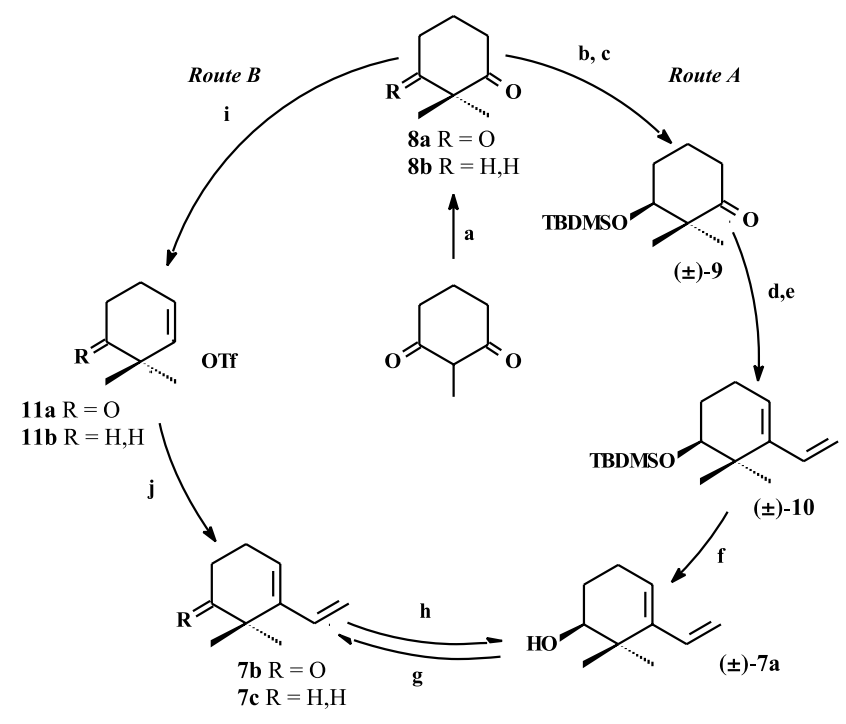

Reagents and Conditions: (a) MeI, $t$-BuOK, $t$-BuOH, $40-50{ }^{\circ} \mathrm{C}, 72 \mathrm{~h}$, $82 \%$; (b) $\mathrm{NaBH}_{4}, \mathrm{MeOH},-10{ }^{\circ} \mathrm{C}, 1 \mathrm{~h}, 74 \%$; (c) TBDMSCl, imidazole, DMF, 50-60 ${ }^{\circ} \mathrm{C}, 48 \mathrm{~h}, 90 \%$; (d) vinylMgBr, $\mathrm{CeCl}_{3}$, THF, $-78{ }^{\circ} \mathrm{C}, 2 \mathrm{~h}$, $95 \%$; (e) $\mathrm{CuSO}_{4}$, silica gel, $\mathrm{CCl}_{4}, 50{ }^{\circ} \mathrm{C}, 1 \mathrm{~h}, 55 \%$; (f) $\mathrm{HF}, \mathrm{CH}_{3} \mathrm{CN}, 24 \mathrm{~h}$, rt., $51 \%$; (g) oxidation not performed; (h) $\mathrm{NaBH}_{4}, \mathrm{MeOH},-10{ }^{\circ} \mathrm{C}, 1 \mathrm{~h}$, $95 \%$; (i) $\mathrm{R}=\mathrm{O} \mathrm{Tf}_{2} \mathrm{O}$, pyridine, $\mathrm{CH}_{2} \mathrm{Cl}_{2}$, rt., 7 days, $60 \%$; $\mathrm{R}=\mathrm{H}, \mathrm{H}_{\mathrm{Tf}} \mathrm{O}$, pyridine, $\mathrm{CH}_{2} \mathrm{Cl}_{2}$, rt., $24 \mathrm{~h}, 90 \%$; (j) vinylSnBu${ }_{3}, \mathrm{LiCl}$, $\left[\mathrm{Pd}\left(\mathrm{PPh}_{3}\right)_{4}\right], \mathrm{THF}$ (reflux), $12 \mathrm{~h}, \mathrm{R}=\mathrm{O}(85 \%) ; \mathrm{R}=\mathrm{H}, \mathrm{H}(70 \%)$.

Scheme 2. Synthetic strategies to obtain vinylcyclohexene ( \pm )-7a, $7 \mathbf{b}, \mathbf{7 c}$ and $( \pm)-\mathbf{1 0}$

abietanoid $o$-quinones, except that the Stang's protocol ${ }^{16}$ (triflic anhydride instead of $N$-phenyltriflimide ${ }^{17} / \mathrm{LDA}$ system) was applied to obtain monoenoltriflate 11a (60\% yield). As supposed, a palladium-catalysed reaction (Stille cross coupling ${ }^{18}$ ) performed with 11a and the vinylstannane ${ }^{19}$ built-up the diene moiety of $\mathbf{7 b}$ in good yield (85\%).

Reduction of $\mathbf{7 b}$ was accomplished with $\mathrm{NaBH}_{4}$ to furnish ( \pm )-7a in $97 \%$ yield. This alternative route to $( \pm)$ $7 \mathbf{a}$ and $7 \mathbf{b}$ is shorter and displays a significant overall yield enhancement (49\%) compared to route A. Peripheral findings from our studies in route $\mathbf{B}$ should be mentioned. First, to the best of our knowledge, the selective monotriflation of $\mathbf{8 a}$ was never reported before, therefore Stang's protocol provides an especially serviceable way to achieve the 2,2-disubstituted cyclohexane-1,3-diones selective functionalization. Second, the ketovinylcyclohexene $7 \mathbf{b}$ sounds a pivotal intermediate to access bicyclic terpenes possessing a ketone group at position 6 , as in salmantic acid 6.

With ( \pm$)-\mathbf{7 a}, \mathbf{7 b}$ and $( \pm)-\mathbf{1 0}$ in hand, we turned to the crucial Diels-Alder reaction (Scheme 3). First of all, diene $( \pm)$-10 and methyl tiglate were subjected to several DA reaction conditions and in most of them the adducts were not detected (Table 1, entries 1 to 5). This problem was overcome when we applied more drastic reaction conditions. Based on the GC/MS analyses of the reaction mixtures, best results were obtained with the use of higher temperatures and pressures (Table 1, entries 6 and 7).

Table 1. Diels-Alder reaction conditions applied to diene ( \pm -)-10 and methyl tiglate.

\begin{tabular}{ccccccc}
\hline Entry & Catalyst & Solvent & $\begin{array}{c}\text { Pressure } \\
(\mathrm{kbar})\end{array}$ & $\begin{array}{c}\text { Temperature } \\
\left({ }^{\circ} \mathrm{C}\right)\end{array}$ & $\begin{array}{c}\text { Time } \\
(\text { days })\end{array}$ & $\begin{array}{c}\text { Yield } \\
(\%)^{*}\end{array}$ \\
\hline 1 & none & toluene & atm. & rt. & 0.5 & - \\
2 & $\mathrm{AlCl}_{3}$ & toluene & atm. & rt. & 0.5 & - \\
3 & $\mathrm{AlCl}_{3}$ & toluene & atm. & 80 & 0.5 & - \\
4 & $\left(\mathrm{CH}_{3}\right)_{2} \mathrm{AlCl}$ & $\mathrm{CH}_{2} \mathrm{Cl}_{2}$ & atm. & -78 & 0.5 & - \\
5 & $\left(\mathrm{CH}_{3}\right)_{2} \mathrm{AlCl}$ & $\mathrm{CH}_{2} \mathrm{Cl}_{2}$ & atm. & rt. & 0.5 & - \\
6 & none & neat & $* *$ & 110 & 2 & $<10$ \\
7 & none & $\mathrm{CH}_{2} \mathrm{Cl}_{2}$ & 4 & 110 & 7 & $<3$ \\
\hline
\end{tabular}

$*=$ combined yield of the adducts. $* *=$ the reaction was carried out in a sealed glass ampoule. atm. $=$ atmospheric pressure. $\mathrm{rt} .=$ room temperature

Thus, the presence of adducts was characterized by compounds possessing fragments of $m / z 380,323,265$, $248,189,171$ and 119 in their mass spectra. Due to low yields the adducts were neither isolated nor further characterized.

The low reactivity of diene $( \pm)-\mathbf{1 0}$ in DA reaction with methyl tiglate was assigned to the steric hindrance of the bulky TBDMS group, which was therefore removed to afford $( \pm)-7 \mathbf{a}$. In keeping with our plan, the diene $( \pm)-7 \mathbf{a}$ and methyl tiglate were submitted to several DA conditions and the best results were obtained at $4 \mathrm{kbar}$ and $110{ }^{\circ} \mathrm{C}$ (Table 2, entry 1).

Table 2. Diels-Alder reaction conditions applied to diene ( \pm )-7a and methyl tiglate.

\begin{tabular}{ccccccc}
\hline Entry & Catalyst & Solvent & $\begin{array}{c}\text { Pressure } \\
(\mathrm{kbar})\end{array}$ & $\begin{array}{c}\text { Temperature } \\
\left({ }^{\circ} \mathrm{C}\right)\end{array}$ & $\begin{array}{c}\text { Time } \\
(\text { days })\end{array}$ & $\begin{array}{c}\text { Yield } \\
(\%)^{*}\end{array}$ \\
\hline 1 & none & neat & 4 & 110 & 7 & 46 \\
2 & none & neat & $* *$ & 110 & 7 & 27 \\
3 & none & toluene & atm. & 70 & 1 & - \\
4 & $\left(\mathrm{CH}_{3}\right)_{2} \mathrm{AlCl}$ & $\mathrm{CH}_{2} \mathrm{Cl}_{2}$ & atm. & -78 and rt. & 0.5 and $1-$ \\
\hline
\end{tabular}

$*=$ combined yield of the adducts. $* *=$ the reaction was carried out in a sealed-glass ampoule. atm. $=$ atmospheric pressure. $\mathrm{rt}$. = room temperature.

Under these conditions only four of the eight possible adducts (Scheme 3 ) were produced as detected by GC/MS analyses using a DB-5 capillary column $[( \pm)-\mathbf{1 2}(42 \%)$, $( \pm)-\mathbf{1 3}(13 \%),( \pm)-\mathbf{1 4}(21 \%)$ and $( \pm)-\mathbf{1 5}(24 \%)]$, all of them showing the same molecular ion at $\mathrm{m} / \mathrm{z} 266$ and base peak either at $m / z 207[( \pm)-12], 119[( \pm)-\mathbf{1 3}]$ or $189[( \pm)-14$ and $( \pm)-\mathbf{1 5}$, the remaining fragments composed a similar pattern for the four isomers. After several attempts the mixture was resolved using reverse phase HPLC, 


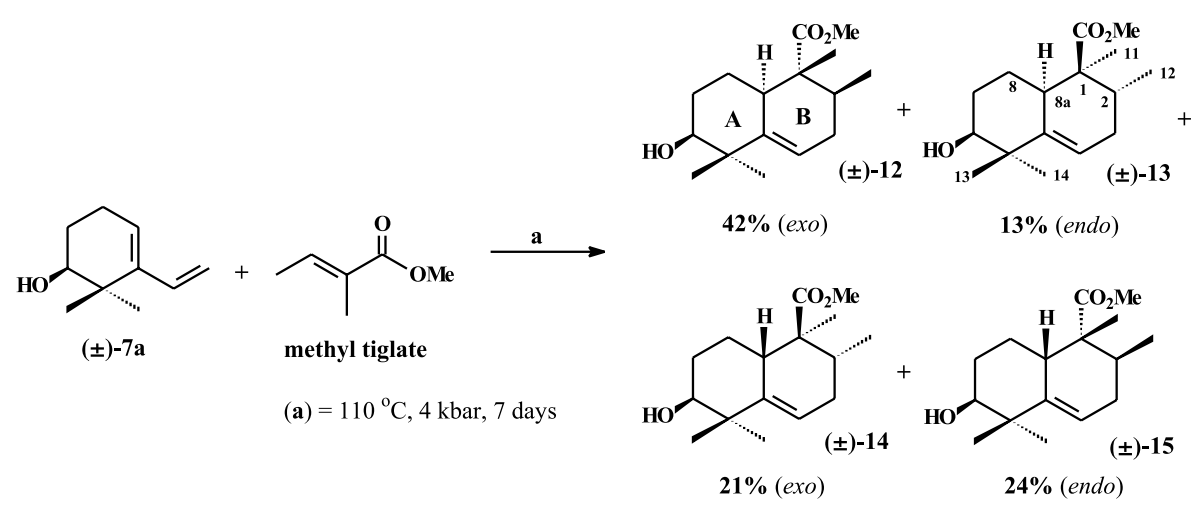

Scheme 3. Cycloadducts of the Diels-Alder reaction between ( \pm -7a and methyl tiglate.

( $\mu$-Bondapak TM-C18 (300 x $7.8 \mathrm{~mm}$ ) eluted with $\mathrm{MeOH} /$ $\mathrm{H}_{2} \mathrm{O}(7: 3, \mathrm{v} / \mathrm{v})$, and a HP-1047A refractive index detector.

Structures $( \pm)-\mathbf{1 2},( \pm)-\mathbf{1 3},( \pm)-\mathbf{1 4}$ and $( \pm)$-15 were assigned to the isolated compounds based on spectroscopic analyses (mainly 1D and 2D NMR experiments: ${ }^{1} \mathrm{H}$ and ${ }^{13} \mathrm{C}$ NMR, DEPT, nOe difference, ${ }^{1} \mathrm{H},{ }^{1} \mathrm{H}$ and ${ }^{1} \mathrm{H},{ }^{13} \mathrm{C}$ correlation spectra). From the ${ }^{1} \mathrm{H}$ NMR analysis the four adducts were partitioned into two groups (I and II) of diastereomers based on the multiplicity of the carbinolic hydrogen H-6 (Table $3)$. Octalins of group I depicted broad signals (equatorial H-6) at $\delta 3.50$ and 3.43 assigned to $( \pm)-\mathbf{1 2}$ and $( \pm)-\mathbf{1 3}$, respectively. Octalins of group II depicted double doublets (axial H-6) at $\delta 3.24(J 13$ and $4 \mathrm{~Hz})$ and $3.16(J 13$ and 4 $\mathrm{Hz})$ assigned to $( \pm)-\mathbf{1 4}$ and $( \pm)-\mathbf{1 5}$ respectively.

Molecular models of the 8 possible diastereoisomers clearly pointed out that the ring A (Scheme 3 ) predominant conformation was closely related to the C-8a and C-6 relative configurations. Thus, the $\mathrm{H}-6 / \mathrm{H}-8 \mathrm{a}$ cis octalins depicted an equatorial carbinolic hydrogen $[( \pm)-12$ and $( \pm)$ 13], while H-6/H-8a trans octalins [( \pm -14 and ( \pm )-15], depicted axial carbinolic hydrogens and equatorial hydroxyl groups.

It was further observed that H-8a at $\delta 2.82[( \pm)-\mathbf{1 2}]$, $2.72[( \pm)-\mathbf{1 3}], 2.22[( \pm)-\mathbf{1 4}]$ and $2.08[( \pm)-\mathbf{1 5}]$, in all octalins, only possessed $\mathrm{H}-1$ hydrogens as neighbours (unambigously assigned by 2D NMR spectra: ${ }^{1} \mathrm{H},{ }^{1} \mathrm{H}$ COSY, one and multiple bonds ${ }^{13} \mathrm{C},{ }^{1} \mathrm{H}$ correlations, HETCOR and COLOC), which restricted the diastereomeric structures to a unique set of regioisomers, those possessing the desired quaternary carbon (C-1) adjacent to $\mathrm{C}-8 \mathrm{a}$. The long range heteronuclear scalar couplings $\left({ }^{3} J_{C, H}\right)$ between $\mathrm{C}-8 \mathrm{a}$ and the methyl connected to a quaternary center corroborated the above-mentioned conclusion.

With the relative configuration of C-6 and C-8a established and the methoxycarbonyl group positioned at $\mathrm{C}-1$, the remaining relative configurations were established by applying the following rationale: of the four octalins isolated, those possessing more deshielded $\mathrm{H}-8 \mathrm{a}$, at $\delta 2.82$ $[( \pm)-\mathbf{1 2}]$ and $2.72[( \pm)-14]$, were assigned to the H-8a/ $\mathrm{CO}_{2} \mathrm{Me}$ cis relative configuration, while those two with more shielded H- $8 \mathrm{a}$, at $\delta 2.22[( \pm)-\mathbf{1 3}]$ and $2.08[( \pm)-\mathbf{1 5}]$ were identified as trans $\mathrm{H}-8 \mathrm{a} / \mathrm{CO}_{2} \mathrm{Me}$.

Thus, structures for $( \pm)-\mathbf{1 2}$ and $( \pm)-\mathbf{1 3}$, belonging to group I (equatorial carbinolic hydrogen), and depicting $\mathrm{H}$ 8a chemical shifts in $\delta 2.82$ and 2.22, respectively, were established as depicted in Scheme 3. While those of $( \pm)$ $\mathbf{1 4}$ and ( \pm )-15, belonging to group II, (axial carbinolic hydrogen) with $\mathrm{H}-8 \mathrm{a}$ at $\delta 2.72$ and 2.08 , respectively, were established as depicted in Scheme 3. The full assignment of the signals was only achieved with additional informations of the long range scalar interactions $\left({ }^{1} \mathrm{H},{ }^{13} \mathrm{C}\right.$ COLOC) and nOe differential spectra. The full ${ }^{1} \mathrm{H}$ and ${ }^{13} \mathrm{C}$ chemical shifts assignments for these four octalins are shown in the experimental section.

The conformation in solution and the most significative nOe enhancements are depicted in Figure 1. Structures $( \pm)-12$ and $( \pm)-\mathbf{1 5}$ were further confirmed by X-ray

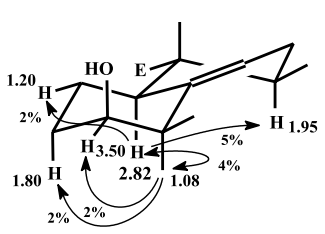

$( \pm)-12$

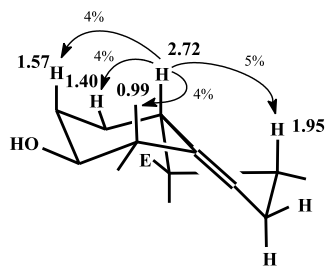

$( \pm)-14$

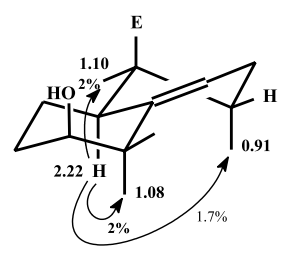

$( \pm)-13$

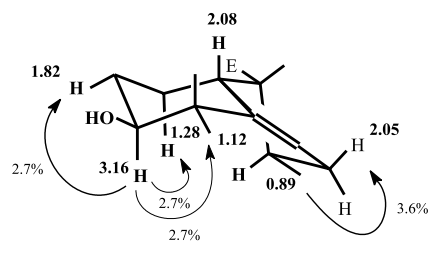

( \pm -15
Figure 1. Major nOe enhancements for octalins $( \pm)-\mathbf{1 2},( \pm)-13,( \pm)-14$ and (土)-15. 


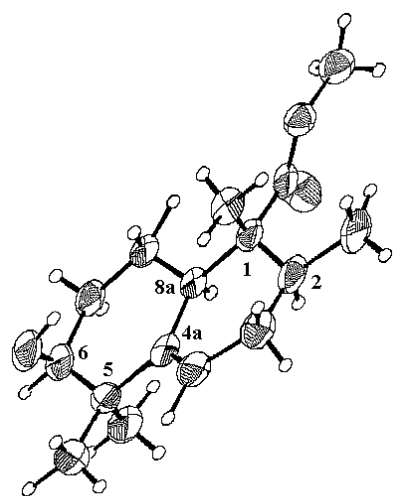

$( \pm)-12$

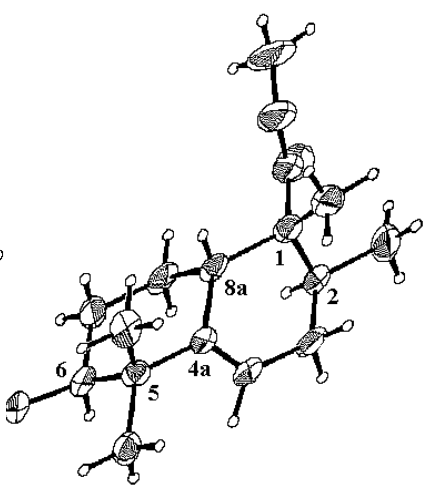

$( \pm)-15$

Figure 2. ORTEP drawing of X-ray crystallographically determined structures of $( \pm)-\mathbf{1 2}$ and $( \pm)-\mathbf{1 5}$. Thermal ellipsoids drawn to the $50 \%$ probability.

diffraction analysis and the ORTEP drawings are depicted in Figure 2.

Based on these results we have concluded that the regioselectivity of this reaction was maintained similar to that observed in the synthesis of mamanuthaquinone ${ }^{6}(\mathbf{3})$ but the stereoselectivity exo was somewhat lost under the influence of either the hydroxyl group or the structural changes of the dienophile.

With the purpose of better understanding the stereoelectronic effects of this DA reaction we envisioned to analyse de behaviour of the ketodiene $7 \mathbf{b}$ with methyl tiglate and methyl angelate ${ }^{20}$ as dienophiles. Both reactions were performed in sealed ampoules at $170{ }^{\circ} \mathrm{C}$ ( 7 days).

Reaction of $\mathbf{7 b}$ with methyl angelate furnished two products in a 2:1 ratio (Scheme 4). Total in situ isomerization of the major adduct was responsible for the isolation of compound ( \pm )-18. The minor component $( \pm)$ $\mathbf{1 9}$ was obtained in a 1:1 mixture with $( \pm)$-18. From the spectral data comparison of $( \pm)$-18 with those of the mixture structure of the adduct $( \pm)$-19 was established as depicted in Scheme 4. However it is worthwhile mentioning that the reaction of $\mathbf{7 b}$ with methyl tiglate produced two adducts in a 1:1 ratio possessing the regiochemistry of $( \pm)-\mathbf{1 8}^{21}$.
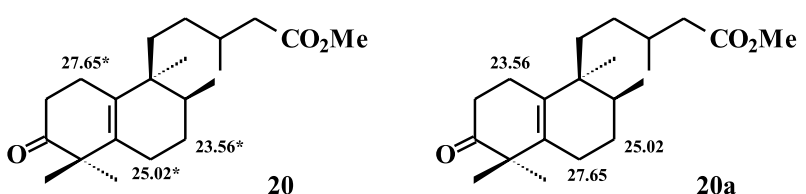

(*) interchangeable

Figure 3. Suggested assignment (20a) for some ${ }^{13} \mathrm{C}$ chemical shifts reported for the salmantic acid derivative 20.

Thus the subtle change of the dienophile (methyl angelate $\rightarrow$ methyl tiglate) was responsible for the high regioselectivity of this reaction.

As the bicyclic framework of compound ( \pm )-18 and that of the methyl ester $\mathbf{2 0}$ of salmantic acid (6) are equal the ${ }^{1} \mathrm{H}$ and ${ }^{13} \mathrm{C}$ NMR chemical shifts of the corresponding carbons and hydrogens were expected to be highly similar. Therefore some doubts about the chemical shifts of carbons 1, 6 and 7 (diterpene numbering system) of the derivative 20 were cleared by comparison with the full assignment of $( \pm)-\mathbf{1 8}$ and our suggestion of assignment is depicted in structure 20a (Figure 3).

Thus based on the above results we observed that octalins possessing rings $\mathrm{A} / \mathrm{B}$ of the rearranged drimane skeleton, with a $\mathrm{C} 1-\mathrm{Me} / \mathrm{C} 2-\mathrm{Me}$ cis relationship, displayed a $\Delta \delta$ about 1 ppm between the vicinal methyl groups, while for those with a trans relationship a $\Delta \delta$ about 6 to $7 \mathrm{ppm}$, independent of the relative configuration between $\mathrm{H}-8 \mathrm{a}$ and C1-Me and of the C-6 substitutent, was observed.

We also realized that our set of data was not complete unless the 6-unsubstituted octalins were synthesized. The latter would provide good standards for a series of natural halimane diterpenes. We have thus embarked on the synthesis of octalin models compounds possessing C1-Me/ C2-Me cis and trans relationship (Scheme 5). Diene 7c was readily available from commercial 2,2dimethylcyclohexanone and using the previously established protocol. The DA reactions between diene $7 \mathbf{c}$ and methyl angelate (reaction 1) and methyl tiglate
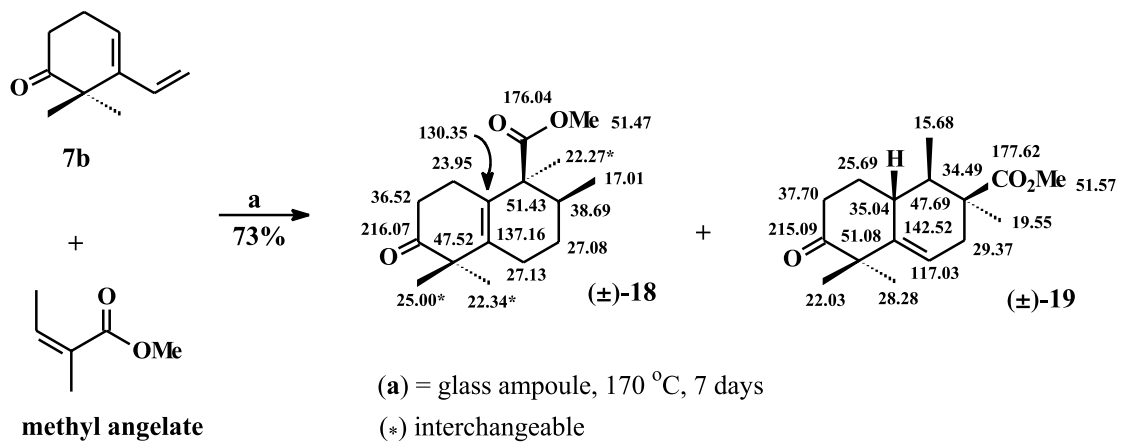

(a) = glass ampoule, $170^{\circ} \mathrm{C}, 7$ days
$(*)$ interchangeable

Scheme 4. Cycloadducts of the Diels-Alder reaction between $\mathbf{7 b}$ and methyl angelate. 

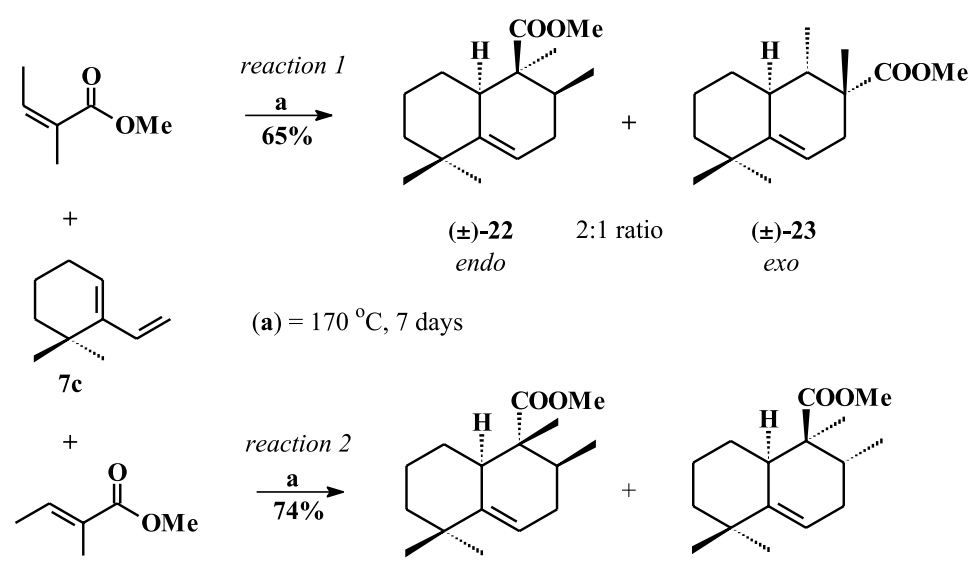

(a) $=170{ }^{\circ} \mathrm{C}, 7$ days

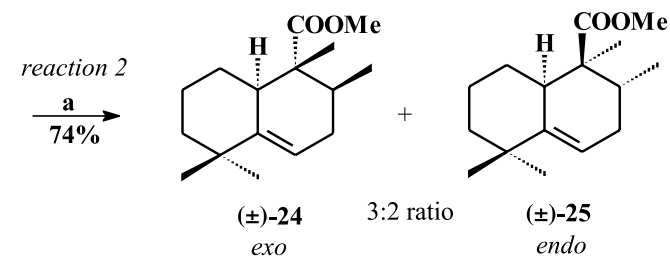

Scheme 5. Diels-Alder reactions using 7c and methyl angelate (reaction 1) or methyl tiglate (reaction 2) as dienophiles.
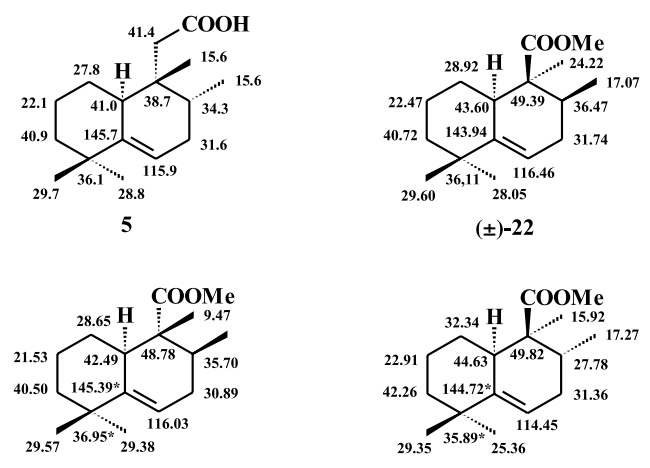

$( \pm)-24$

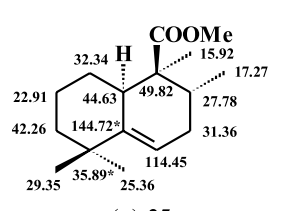

$( \pm)-25$

(*) interchangeable values between the same carbons of $( \pm)-24$ and $( \pm)-25$.

Figure 4. ${ }^{13} \mathrm{C}$ NMR chemical shifts of natural product 5 and synthetic standards $( \pm)-22,( \pm)-24$ and $( \pm)$-25.

(reaction 2) acting both as solvent and dienophiles were carried out in sealed ampoules at $170{ }^{\circ} \mathrm{C}$ for 7 days. Reactions 1 and 2 furnished mixtures of adducts (Scheme 5). Purification of the reaction mixture by preparative TLC on silica gel $\mathrm{AgNO}_{3} 10 \%$ (w/w) provided highly enriched major adduct $( \pm)-22$ (endo adduct) from which a full set of spectroscopic data $\left({ }^{1} \mathrm{H} \mathrm{NMR},{ }^{13} \mathrm{C}\right.$ NMR, gCOSY, HSQC, NOESY and MS) was obtained, allowing good structural characterization. The $\Delta \delta$ between C1-Me and C2-Me of $( \pm)-22$ was 7 ppm in good agreement with the above mentioned trans relationship. This rule was validated by observing the reported ${ }^{13} \mathrm{C}$ chemical shifts of some natural products like $4^{7}$ possessing this octalin framework.

Notwithstanding this successful comparison this rule failed when applied to one of the natural products we had isolated from Vellozia flavicans, the tetra-nor-halimanoic acid $(\mathbf{5})^{4}$, which depicted a $\Delta \delta=0 \mathrm{ppm}$. We have also

realized that a cis relationship instead of the reported trans would better match our observations.

This prompted us to reanalyse all spectroscopic data in order to ascertain that no additional misassignments were made at that time and indeed most signals were correctly assigned but for minor drawing misprinting. Thus, comparison of the spectroscopic data of $( \pm)-22,( \pm)-24$ and ( \pm )-25 (Figure 4 ) led us to revise the proposed structure of $\mathbf{5}$ as depicted in Figure 5.

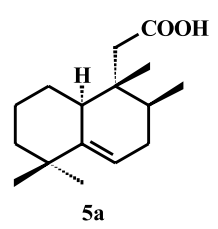

Figure 5. Suggested relative stereochemistry (5a) for the natural product $\mathbf{5}$.

In conclusion, we have achieved the synthesis and spectroscopic characterization of useful rearranged unsaturated drimane derivatives. This study corroborates with the idea that the regio and stereochemical outcome of the Diels-Alder reactions depend on the double bond stereochemistry of the acrilate derivatives and as a rule tiglate derivatives display high regioselectivity as observed in the synthesis of mamanuthaquinone ${ }^{6}$. Finally the spectrometric characterization of the compounds $( \pm)-\mathbf{1 2}$, $( \pm)-13,( \pm)-14,( \pm)-15,( \pm)-18,( \pm)-19,( \pm)-22,( \pm)-23,( \pm)-$ 24 and $( \pm)-25$ is of great help to identify new natural products possessing this octalin moiety which can be so deceiving in determining its relative configuration. 


\section{Experimental}

Melting points were recorded with a Kofler hot plate set up in a microscope Thermopan model (C. Reichert Optische Werke AG). FTIR Spectra were taken on a Perkin Elmer 298 spectrophotometer. ${ }^{1} \mathrm{H}$ NMR spectra were recorded with a Varian GEMINI 300 (300 MHz, Varian) or Bruker AC $300 \mathrm{P}(300 \mathrm{MHz})$ spectrometers. $\mathrm{CDCl}_{3}$ was used as the solvent, with $\mathrm{Me}_{4} \mathrm{Si}$ (TMS) as internal standard. ${ }^{13} \mathrm{C}$ NMR spectra were obtained with a Varian GEMINI 300 (75.5 $\mathrm{MHz}$ ) or a Bruker AC300P (75.5 MHz) spectrometers. $\mathrm{CDCl}_{3}$ (77.0 ppm) was used as internal standard. Signals of methyl, methylene, methine and carbons nonbonded to hydrogen were recognized using DEPT 90 and 135 spectra. 2D NMR spectroscopy experiments were performed with standard homonuclear $\mathrm{H}, \mathrm{H}$ and heteronuclear $\mathrm{H}, \mathrm{X}$ correlation pulse sequences available in the spectrometers. The GC/MS analyses were carried on a HP-5890/5970 system equipped with either a J\&W Scientific DB-5 fused silica capillary column $(30 \mathrm{~m} \times 0.25 \mathrm{~mm} \times 0.25 \mu \mathrm{m})$ or a chiral column heptakis-(2,6-dimethyl-3-pentyl)- $\beta$-cyclodextrin (20m x $0.25 \mathrm{~mm} \times 0.25 \mu \mathrm{m})$. Temperature program $1=100{ }^{\circ} \mathrm{C}$ $\left(2{ }^{\circ} \mathrm{C} \min ^{-1}\right)-180{ }^{\circ} \mathrm{C}$; program $2=55^{\circ} \mathrm{C}\left(2{ }^{\circ} \mathrm{C} \min ^{-1}\right)-$ $80^{\circ} \mathrm{C}$. and program $3=125^{\circ} \mathrm{C}\left(30^{\circ} \mathrm{C} \mathrm{min}{ }^{-1}\right)-150^{\circ} \mathrm{C}$. Injector and detector temperature were both $250^{\circ} \mathrm{C}$. Helium was used as the carrier gas. The MS were taken at $70 \mathrm{eV}$. Scanning speed was 0.84 scan s$^{-1}$ from $\mathrm{m} / \mathrm{z} 40$ to 550 .

\section{2,2-Dimethylcyclohexane-1,3-dione (8a)}

To a $t-\mathrm{BuOK} / t-\mathrm{BuOH}$ solution prepared with potassium $(1.37 \mathrm{~g}, 35 \mathrm{mmol})$ and $t$-butanol $(70 \mathrm{~mL}), 2$-methylcyclohexane-1,3-dione (3.09 g, $24.5 \mathrm{mmol}$ ) was added. The resulting suspension was stirred for $30 \mathrm{~min}$. at rt. and then MeI ( $3.48 \mathrm{~g}, 24.5 \mathrm{mmol})$ was added. The reaction was heated $\left(40-50^{\circ} \mathrm{C}\right)$ and further stirred for 3 days. Usual work-up and kugelrohr apparatus $(4 \mathrm{~mm} \mathrm{Hg}$ ) distillation provided $8 \mathbf{a}(2.81$ $\mathrm{g}, 82 \%$ yield). Recrystallization in hexane. $(10 \mathrm{~mL})$ and $\mathrm{CH}_{2} \mathrm{Cl}_{2}$ (2 drops), furnished colorless crystals. $\mathrm{Mp} 35-36^{\circ} \mathrm{C}$ (lit..$^{22}$ : $38-39^{\circ} \mathrm{C}$ ). Anal. calcd for $\mathrm{C}_{8} \mathrm{H}_{12} \mathrm{O}_{2}$ : C, 68.48; $\mathrm{H}, 8.63$. Found: C, 68.54; H, 8.63\%; IR $v_{\max } / \mathrm{cm}^{-1} 2981,2867,1728$, 1697, 1464, 1381, 1316, 1133, 1029 (film); ${ }^{1} \mathrm{H}$ NMR (300 $\left.\mathrm{MHz}, \mathrm{CCl}_{4}\right) \delta 1.23$ (s, 6H), 1.93 (quint., $J 6.7 \mathrm{~Hz}, 2 \mathrm{H}$ ), 2.60 $(\mathrm{t}, J 6.7 \mathrm{~Hz}, 4 \mathrm{H}) ;{ }^{13} \mathrm{C} \mathrm{NMR}\left(75.46 \mathrm{MHz}, \mathrm{CCl}_{4}\right) \delta 17.83$, 21.88, 36.80, 60.92, 207.40; $\mathrm{m} / \mathrm{z} 140\left(\mathrm{M}^{+}, 34 \%\right), 112(2)$, 111 (2), 97 (82), 70 (64), 55 (62) and 42 (100).

\section{3-t-Butyldimethylsilyloxy-2,2-dimethylcyclohexanone ( \pm )-(9)}

$\mathrm{NaBH}_{4}(236.0 \mathrm{mg}, 6.3 \mathrm{mmol})$ was slowly added to 2,2dimethylcyclohexane-1,3-dione (8a) (3.5 g, $25 \mathrm{mmol})$, in methanol $(25 \mathrm{~mL})$. The reaction was stirred at $-10{ }^{\circ} \mathrm{C}$ until reaction completion, as monitored by TLC (hexane - ethyl acetate $7: 3)$. Brine $(30 \mathrm{~mL})$ was added to the reaction after addition of few drops of $\mathrm{HCl} 1 \mathrm{~mol} \mathrm{~L}^{-1}$ and evaporation of the methanol. The resulting aqueous mixture was extracted with $\mathrm{CH}_{2} \mathrm{Cl}_{2}(5 \times 20 \mathrm{~mL})$. The organic layer was washed with brine $(3 \times 20 \mathrm{~mL})$ and dried over anhydrous $\mathrm{Na}_{2} \mathrm{SO}_{4}$. The residue obtained $(3.21 \mathrm{~g})$ from the solvent evaporation was purified by column chromatography on silica gel (hexane/ethyl acetate 12\%, v/v), delivering ( \pm )-3-hydroxy2,2-dimethylcyclohexanone (2.63 g, 74\% yield). An analytical sample was purified by reduced pression fractionated distillation. Bp $96-97{ }^{\circ} \mathrm{C} / 4.10^{-3}$ bar (lit. ${ }^{23}$ : 85$87^{\circ} \mathrm{C} / 5.10^{-3}$ bar). IR $v_{\max } / \mathrm{cm}^{-1} 3454,2943,2874,1705$, 1452, 1382, 1056 (film); $\mathrm{m} / \mathrm{z} 142\left(\mathrm{M}^{+}, 14 \%\right), 124$ (15), 98 (50), 82 (100), 71 (65), 67 (56), 43 (52), 41 (28) and 40 (45).

To a stirred solution of ( \pm )-3-hydroxy-2,2-dimethylcyclohexanone $(1.00 \mathrm{~g}, 7 \mathrm{mmol})$ in anhydrous DMF (20 $\mathrm{mL})$ at rt., imidazole $(1.420 \mathrm{~g}, 20.8 \mathrm{mmol})$ and $t$-butyldimethylsilyl chloride $(1.56 \mathrm{~g}, 10.4 \mathrm{mmol})$ were sequentially added. The reaction mixture was further stirred at $60{ }^{\circ} \mathrm{C}$ for $48 \mathrm{~h}$. Sodium bicarbonate solution $(5 \%, 40$ $\mathrm{mL})$ and diethyl ether $(30 \mathrm{~mL})$ were added. Usual workup and purification by column chromatography on silica gel (hexane/ethyl acetate $5 \%, \mathrm{v} / \mathrm{v}$ ) furnished silylketone

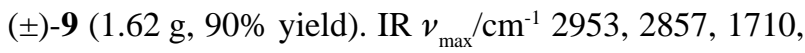
1472, 1385, 1362, 1255, 1082, 868, 834, 775 (film); ${ }^{1} \mathrm{H}$ NMR $\left(300 \mathrm{MHz}, \mathrm{CCl}_{4}\right) \delta 0.05(\mathrm{~s} 6 \mathrm{H}), 0.90(\mathrm{~s}, 9 \mathrm{H}), 1.03$ $(\mathrm{s}, 3 \mathrm{H}), 1.07(\mathrm{~s}, 3 \mathrm{H}), 1.60(\mathrm{~m}, 1 \mathrm{H}), 1.75(\mathrm{~m}, 1 \mathrm{H}), 1.90(\mathrm{~m}$, $1 \mathrm{H}), 2.00(\mathrm{~m}, 1 \mathrm{H}), 2.30(\mathrm{~m}, 2 \mathrm{H}), 3.62(\mathrm{dd}, J 7.6$ and $3 \mathrm{~Hz}$, $1 \mathrm{H}) ;{ }^{13} \mathrm{C}$ NMR $\left(75.46 \mathrm{MHz}, \mathrm{CCl}_{4}\right) \delta-4.82,-4.08,18.19$, 20.29, 20.43, 23.06, 25.97, 29.73, 36.71, 51.35, 78.22, 210.29; m/z $256\left(\mathrm{M}^{+}, 1 \%\right), 241$ (1), 199 (79), 171 (13), 143 (17), 141 (28), 128 (18), 115 (82), 107 (15), 75 (100), 73 (38), 69 (20), 59 (12), 55 (11) and 41 (13).

4-(t-Butyldimethylsiloxy)-3,3-dimethyl-2-vinylcyclohexene ( \pm )-(10)

To a round bottom flask $(100 \mathrm{~mL})$ under inert atmosphere $\left(\mathrm{N}_{2}\right)$, containing anhydrous $\mathrm{CeCl}_{3}(9.69 \mathrm{~g})$, THF $(40 \mathrm{~mL})$ and vinylMgBr $\left(1 \mathrm{~mol} \mathrm{~L}^{-1}\right.$ in THF, $26 \mathrm{~mL}$, $26 \mathrm{mmol})$, the silylketone $( \pm)-9(4.92 \mathrm{~g}, 19 \mathrm{mmol})$, diluted in anhydrous THF $(10 \mathrm{~mL})$, was added at $-78{ }^{\circ} \mathrm{C}$. The resulting mixture was stirred for $30 \mathrm{~min}$. The reaction was poured onto a $4 \%$ acetic acid aqueous solution $(50 \mathrm{~mL})$. Usual work-up furnished a residue $(5.4 \mathrm{~g})$, which was purified by column chromatography on silica gel (hexane/ $\mathrm{CH}_{2} \mathrm{Cl}_{2} 4: 1$, followed by $3: 2 \mathrm{v} / \mathrm{v}$ ), yielding a diastereomeric mixture of alcohols (5.13 g, 95\% yield). The alcohols 
mixture (500.0 mg, $1.9 \mathrm{mmol})$, in dry $\mathrm{CCl}_{4}(15 \mathrm{~mL})$, were heated to $50-60{ }^{\circ} \mathrm{C}$ for $2 \mathrm{~h}$ in the presence of $\mathrm{CuSO}_{4} / \mathrm{SiO}_{2}$ $(2.0 \mathrm{~g})$ previously prepared ${ }^{14}$. The reaction was left at rt. overnight. Filtration of the $\mathrm{CuSO}_{4} / \mathrm{SiO}_{2}$ and usual workup furnished a residue $(480 \mathrm{mg})$ which was purified by column chromatography on silica gel, delivering $( \pm)-10(257 \mathrm{mg}, 55 \%$ yield) as a slightly volatile liquid. IR $v_{\max } / \mathrm{cm}^{-1} 3081,2955,2856,1618,1471,1406,1360$, 1255, 1122, 1081, 1050, 1023, 836, 773 (film); ${ }^{1} \mathrm{H}$ NMR $\left(300 \mathrm{MHz}, \mathrm{CCl}_{4}\right) \delta 0.04(\mathrm{~s}, 3 \mathrm{H}), 0.05(\mathrm{~s}, 3 \mathrm{H}), 0.89(\mathrm{~s}, 9 \mathrm{H})$, $0.97(\mathrm{~s}, 3 \mathrm{H}), 1.02(\mathrm{~s}, 3 \mathrm{H}), 1.63(\mathrm{dd}, J 8$ and $5 \mathrm{~Hz}, 1 \mathrm{H})$, $1.67(\mathrm{~m}, 1 \mathrm{H}), 2.10(\mathrm{~m}, 2 \mathrm{H}), 3.50(\mathrm{dd}, J 8$ and $5 \mathrm{~Hz}, 1 \mathrm{H})$, $4.86(\mathrm{dd}, J 11$ and $2 \mathrm{~Hz}, 1 \mathrm{H}), 5.18(\mathrm{dd}, J 17$ and $2 \mathrm{~Hz}, 1 \mathrm{H}$ ), 5.58 (br, t, $J 3.5 \mathrm{~Hz}, 1 \mathrm{H}$ ), 6.21 (qq, $J 17$ and $11 \mathrm{~Hz}, 1 \mathrm{H}$ ); ${ }^{13} \mathrm{C}$ NMR $\left(75.46 \mathrm{MHz}, \mathrm{CCl}_{4}\right) \delta-5.11,-4.20,17.92,21.50$, 23.80, 25.59, 25.75, 26.95, 38.85, 76.12, 113.40, 120.92, 136.55, 144.11; m/z 209 (12\%), 134 (7), 119 (10), 93 (33), 91 (10), 77 (13), 75 (100), 73 (19), 59 (8), 57 (4), 47 (6) and 41 (9).

\section{2,2-Dimethyl-3-vinylcyclohex-3-en-1-ol ( \pm )-(7a)}

A mixture of $( \pm)-\mathbf{1 0}(250 \mathrm{mg}, 1 \mathrm{mmol})$, in acetonitrile $(60 \mathrm{~mL})$ and $\mathrm{HF} 40 \%(5 \mathrm{~mL})$, was stirred at rt. for $24 \mathrm{~h}$. Powdered $\mathrm{NaHCO}_{3}$ was added to the reaction mixture to neutralize the acid. The reaction was further stirred for 12 $\mathrm{h}$ at $\mathrm{rt}$.. The solid phase was separated by filtration and washed with $\mathrm{CH}_{2} \mathrm{Cl}_{2}(30 \mathrm{~mL})$. The organic layer was submitted to the usual work-up yielding $( \pm)-7 \mathbf{a}(73 \mathrm{mg}$, $51 \%$ yield) which was purified by column chromatography on silica gel (hexane/ethyl acetate 9:1, v/v), furnishing pure ( \pm -7a as crystals. Mp 52-53 ${ }^{\circ} \mathrm{C}$. Anal. calcd for $\mathrm{C}_{10} \mathrm{H}_{16} \mathrm{O}: \mathrm{C}$, 78.89; H, 10.59. Found C, 79.07; H, 10.55; IR $v_{\max } / \mathrm{cm}^{-1}$ 3374, 3081, 2965, 2867, 1611, 1466, 1359, 1184, 1120, 1064, 1036, 1008, 907, 817 (film); ${ }^{1} \mathrm{H}$ NMR (300 MHz, $\left.\mathrm{CDCl}_{3}\right) \delta 1.07$ (s, 3H), 1.12 (s, 3H), 1.67 (qq, $J 16,5$ and $1.5 \mathrm{~Hz}, 1 \mathrm{H}), 1.81(\mathrm{~m}, 1 \mathrm{H}), 2.18(\mathrm{~m}, 2 \mathrm{H}), 3.57(\mathrm{dd}, J 9$ and $3 \mathrm{~Hz}, 1 \mathrm{H}), 4.96(\mathrm{dd}, J 11$ and $2.2 \mathrm{~Hz}, 1 \mathrm{H}), 5.29(\mathrm{dq}, J 17$ and $2.2 \mathrm{~Hz}, 1 \mathrm{H}$ ), 5.74 (br, t, $J 3.5 \mathrm{~Hz}, 1 \mathrm{H}$ ), 6.29 (qq, $J 17$ and $11 \mathrm{~Hz}, 1 \mathrm{H}) ;{ }^{13} \mathrm{C}$ NMR $\left(75.46 \mathrm{MHz}, \mathrm{CDCl}_{3}\right) \delta 21.65,23.22$, 26.12, 26.27, 38.44, 75.73, 113.84, 121.72, 136.36, 143.25; $\mathrm{m} / \mathrm{z} 152\left(\mathrm{M}^{+}, 1 \%\right), 134(29), 119(100), 105(9), 93$ (93), 91 (49), 79 (29), 77 (37), 67 (18), 43 (39) and 41 (44).

\section{6,6-Dimethyl-5-oxocyclohex-1-enyltrifluoro- methanesulphonate (11a)}

To a mixture of 1,3-dione $\mathbf{8 a}(2.85 \mathrm{~g}, 20 \mathrm{mmol})$ and anhydrous pyridine ( $2.01 \mathrm{~g}, 26 \mathrm{mmol})$, in $\mathrm{CH}_{2} \mathrm{Cl}_{2}(100 \mathrm{~mL})$ at $0{ }^{\circ} \mathrm{C}$, triflic anhydride $(4.30 \mathrm{~mL}, 26 \mathrm{mmol})$ was added. Development of a deep-red colour was observed followed by the formation of a fluffy precipitate. The suspension was stirred at rt. for 7 days, during which parcial solubilization of the solid material and a noticeable darkening of the reaction mixture was observed. Filtration through a Celite ${ }^{\circledast}$ pad followed by usual work-up furnished 11a (3.40 g, 61\% yield) as an oil, after distillation in a kugelrohr apparatus $\left(3.10^{-4}\right.$ bar $)$. IR $v_{\max } / \mathrm{cm}^{-1} 2985,1726$, $1679,1415,1246,1212,1142,1012,929,877,682,608$, 506 (film); ${ }^{1} \mathrm{H}$ NMR $\left(300 \mathrm{MHz}, \mathrm{CDCl}_{3}\right) \delta 1.31(\mathrm{~s}, 6 \mathrm{H})$, $2.45(\mathrm{~m}, 2 \mathrm{H}), 2.60$ (t, $J 6 \mathrm{~Hz}, 2 \mathrm{H}), 5.97(\mathrm{t}, J 4.4 \mathrm{~Hz}, 1 \mathrm{H})$; ${ }^{13} \mathrm{C} \mathrm{NMR}\left(75.45 \mathrm{MHz}, \mathrm{CDCl}_{3}\right) \delta 20.45,22.92,34.78,48.44$, $115.41,118.36$ (quartet, $J(\mathrm{CF}) 320 \mathrm{~Hz}, \mathrm{SO}_{2} \mathrm{CF}_{3}$ ), 151.77, 208.85; m/z $272\left(\mathrm{M}^{+}, 7 \%\right), 230$ (9), 123 (11), 97 (36), 83 (5), 79 (10), 69 (100), 55 (19) and 41 (70); HRMS (M+). Found: 272.03201. Calcd for $\mathrm{C}_{9} \mathrm{H}_{11} \mathrm{O}_{4} \mathrm{SF}_{3}$ : 272.03302 .

\section{2,2-Dimethyl-3-vinylcyclohex-3-en-1-one (7b)}

To a slurry of $\mathrm{LiCl}(1.18 \mathrm{~g}, 28 \mathrm{mmol})$ and $\left[\mathrm{Pd}\left(\mathrm{PPh}_{3}\right)_{4}\right]$ ( $83 \mathrm{mg}, 3 \mathrm{mmol} \%$ ), in anhydrous THF $(40 \mathrm{~mL}$ ), triflate 11a $(655.0 \mathrm{mg}, 2.4 \mathrm{mmol})$ and tri- $n$-butylvinylstannane (753.0 mg, $2.4 \mathrm{mmol}$ ) were added. The solution was refluxed for $12 \mathrm{~h}$, cooled to room temperature and diluted with pentane $(30 \mathrm{~mL})$. The resulting solution was filtered through a Celite ${ }^{\circledR}$ pad. The filtrate was washed with $\mathrm{NH}_{4} \mathrm{OH}$ solution $(2 \times 50 \mathrm{~mL})$, water $(2 \times 50 \mathrm{~mL})$. Usual work-up followed by purification of the crude product by flash chromatography on silica gel (eluted with pentane to remove tri- $n$-butyltin chloride, followed by pentane/diethyl ether $5 \%, \mathrm{v} / \mathrm{v}$ ), furnished $\mathbf{7 b}$ as an oil ( $307 \mathrm{mg}, 85 \%$ yield). IR $v_{\max } / \mathrm{cm}^{-1} 3060,2971,2932,2844,1715,1465,1422$, 1382, 1346, 1216, 1168, 1144, 1044, 987, 912, 822 (film); ${ }^{1} \mathrm{H} \mathrm{NMR}\left(300 \mathrm{MHz}, \mathrm{CDCl}_{3}\right) \delta 1.23(\mathrm{~s}, 6 \mathrm{H}), 2.46(\mathrm{~m}, 2 \mathrm{H})$, $2.55(\mathrm{~m}, 2 \mathrm{H}), 5.06(\mathrm{dd}, J 11$ and $1.8 \mathrm{~Hz}, 1 \mathrm{H}), 5.41(\mathrm{dd}, J$ 17.2 and $1.8 \mathrm{~Hz}, 1 \mathrm{H}), 5.96(\mathrm{t}, J 4.2 \mathrm{~Hz}, 1 \mathrm{H}), 6.27$ (ddm, $J$ 17.2 and $11 \mathrm{~Hz}, 1 \mathrm{H}) ;{ }^{13} \mathrm{C} \mathrm{NMR}\left(75.45 \mathrm{MHz}, \mathrm{CDCl}_{3}\right) \delta$ 24.20, 24.83, 35.30, 46.67, 115.29, 121.64, 135.09,144.40, 215.08; m/z $150\left(\mathrm{M}^{+}, 32 \%\right), 122$ (12), 121 (10), 108 (28), 93 (100), 91 (16), 79 (18), 77 (10), 65 (4) and 55 (4); HRMS $\left(\mathrm{M}^{+}\right)$. Found: 150.10466 . Calcd for $\mathrm{C}_{10} \mathrm{H}_{14} \mathrm{O}$ : 150.1044 .

\section{6,6-Dimethylcyclohex-1-enyl trifluoromethanesulphonate (11b)}

To a mixture of commercial $\mathbf{8 b}(0.920 \mathrm{~g}, 7.3 \mathrm{mmol})$ and anhydrous pyridine $(0.770 \mathrm{~g}, 10 \mathrm{mmol})$, in $\mathrm{CH}_{2} \mathrm{Cl}_{2}(30 \mathrm{~mL})$ at $0{ }^{\circ} \mathrm{C}$, triflic anhydride $(1.63 \mathrm{~mL}, 10 \mathrm{mmol})$ was added. Development of a deep-red color was observed. The reaction was stirred at rt. for $24 \mathrm{~h}$. Usual work-up furnished $\mathbf{1 1 b}$ ( 1.88 $\mathrm{g}, 90 \%$ yield), after distillation in a kugelrohr apparatus (3.10-4 bar). IR $v_{\text {max }} / \mathrm{cm}^{-1} 2974,2942,2877,1677,1413,1245$, 
1209, 1144. 1022, 1000, 969, 932, 874, 617, 609 (film); ${ }^{1} \mathrm{H}$ $\mathrm{NMR}\left(300 \mathrm{MHz}, \mathrm{CDCl}_{3}\right) \delta 1.14(\mathrm{~s}, 6 \mathrm{H}, 2 \mathrm{x} \mathrm{Me}), 1.62-1.66$ $(\mathrm{m}, 4 \mathrm{H}), 2.14-2.20(\mathrm{~m}, 2 \mathrm{H}), 5.66(\mathrm{t}, J 4.1 \mathrm{~Hz}) ;{ }^{13} \mathrm{C} \mathrm{NMR}$ $\left(75.45 \mathrm{MHz}, \mathrm{CDCl}_{3}\right) \delta 18.48,24.87,26.26$ (2 x Me), 35.01, $39.09,116.14,118.40$ (q, $\left.J(\mathrm{CF}) 320 \mathrm{~Hz}, \mathrm{SO}_{2} C \mathrm{~F}_{3}\right), 155.89$; $\mathrm{m} / \mathrm{z} 258\left(\mathrm{M}^{+}, 25 \%\right), 243$ (35), 217 (2), 202 (14), 125 (5), 113 (23), 109 (31), 108 (35), 97 (26), 93 (82), 91 (27), 81 (14), 77 (25), 69 (77), 55 (100), 43 (35) and 41 (35).

\section{3,3-Dimethyl-2-vinylcyclohexene (7c)}

To a slurry of $\mathrm{LiCl}(2.12 \mathrm{~g}, 50 \mathrm{mmol})$ and $\left[\mathrm{Pd}\left(\mathrm{PPh}_{3}\right)_{4}\right]$ (300 mg, $4 \mathrm{mmol} \%$ ), in anhydrous THF (40 mL), triflate $11 b(1.70 \mathrm{~g}, 6.5 \mathrm{mmol})$ and tri- $n$-butylvinylstannane $(2.05$ $\mathrm{g}, 6.5 \mathrm{mmol})$ were added. The solution was refluxed for $12 \mathrm{~h}$, cooled to room temperature, and diluted with pentane $(50 \mathrm{~mL})$. The resulting solution was filtered through a Celite ${ }^{\circledR}$ pad. Usual work-up followed by purification of the crude product by flash chromatography on silica gel (eluted with pentane to remove tri- $n$-butyltin chloride followed by pentane/diethyl ether 5\%, v/v), furnished 7c (616 mg, 70\% yield) as an oil. ${ }^{1} \mathrm{H}$ NMR $\left(300 \mathrm{MHz}, \mathrm{CDCl}_{3}\right) \delta 1.06(\mathrm{~s}$, $6 \mathrm{H}), 1.47$ (m, 2H), 1.58 (m, 2H), $2.04(\mathrm{~m}, 2 \mathrm{H}), 4.91$ (dd, $J$ 11 and $2 \mathrm{~Hz}, 1 \mathrm{H}), 5.27$ (dd, $J 18$ and $2,1 \mathrm{H}), 5.77(\mathrm{t}, J 4$ $\mathrm{Hz}, 1 \mathrm{H}), 6.30$ (ddm, $J 18$ and $11,1 \mathrm{H}) ;{ }^{13} \mathrm{C}$ NMR $(75.45$ $\left.\mathrm{MHz}, \mathrm{CDCl}_{3}\right) \delta 19.13,26.16,28.33$ (2 x Me), 33.15, 39.40, 112.66, 123.05, 137.06, 144.60; m/z $136\left(\mathrm{M}^{+}, 62 \%\right), 121$ (61), 108 (12), 197 (17), 105 (14), 95 (12), 93 (87), 91 (39), 80 (100), 77 (34), 67 (19), 65 (12), 55 (16), 53 (14), 51 (10), 43 (25) and 41 (27).

$\left(1 R^{*}, 2 S^{*}, 6 S^{*}, 8 a R^{*}\right)-( \pm)-(12) ;\left(1 S^{*}, 2 R^{*}, 6 S^{*}, 8 a R^{*}\right)-( \pm)-$ (13); $\left(1 S^{*}, 2 R^{*}, 6 S^{*}, 8 a S^{*}\right)-( \pm)-(14)$ and $\left(1 R^{*}, 2 S^{*}, 6 S^{*}\right.$, $\left.8 a S^{*}\right)-( \pm)-(15)$ 1-Methoxycarbonyl-6-hydroxy-1,2,5,5tetramethyl-1,2,3,5,6,7,8,8a-octahydronaphthalenes

Methyl tiglate $(2.6 \mathrm{~mL})$ and vinylcyclohexene $( \pm)-7 \mathbf{a}$ (460 mg, 3 mmol) were mixed in a Teflon ${ }^{\circledR}$ vial which was closed and introduced in a high pressure apparatus ( $4 \mathrm{kbar})$ and heated at $110^{\circ} \mathrm{C}$ for 7 days. The remaining tiglate was removed in vacuo using a kugelrohr apparatus. The residue (590 mg) was purified by flash chromatography on silica gel (hexane/ethyl acetate $9: 1 \mathrm{v} / \mathrm{v}$ ) to afford a diastereomeric mixture of 4 compounds in a 42:24:21:13 ratio (370 mg, $46 \%$ yield). The diastereomers were resolved by reversed phase HPLC ( $\mu$-Bondapak-C18 column, $300 \times 7.8 \mathrm{~mm}$ ) eluted with $\mathrm{MeOH} / \mathrm{H}_{2} \mathrm{O} 7: 3(\mathrm{v} / \mathrm{v})$ at $2 \mathrm{~mL} \mathrm{~min}^{-1}$ and $400 \mathrm{psi}$, affording octalins $( \pm)-12(42 \%),( \pm)-14(21 \%),( \pm)-13$ $(13 \%)$ and $( \pm)-15(24 \%)$, in increasing elution order.

Octalin ( \pm )-12. Mp 97-98 ${ }^{\circ} \mathrm{C}$. Anal. calcd for $\mathrm{C}_{16} \mathrm{H}_{26} \mathrm{O}_{3}$ : C, 72.14; H, 9.84. Found C, 72.35, H, 9.49\%; IR $v_{\max } / \mathrm{cm}^{-1}$
3419, 3049, 2955-2867, 1724, 1458, 1383,1243, 1194, 1110 (film); ${ }^{1} \mathrm{H}$ NMR (300 MHz, $\left.\mathrm{CDCl}_{3}\right) \delta 0.79$ (d, J 6.4 $\mathrm{Hz}, 3 \mathrm{H}, \mathrm{H}-12$ ), 0.96 (s, 3H, H-11), 1.08 (s, 3H, H-14), 1.16 (s, 3H, H-13), 1.20 (m, 1H, H-8), 1.69 (m, 2H, H-7 and H8), 1.80 (m, 2H, H-3 and H-7), 1.95 (m, 2H, H-2 and H-3), 2.82 (dm, J $13 \mathrm{~Hz}, 1 \mathrm{H}, \mathrm{H}-8 \mathrm{a}), 3.50$ (br, s, 1H, H-6), 3.72 (s, 3H, H-10), 5.55 (m, 1H, H-4); ${ }^{13} \mathrm{C}$ NMR (75.46 MHz, $\left.\mathrm{CCl}_{4}\right) \delta 9.40(\mathrm{C}-11), 16.20(\mathrm{C}-12), 20.60$ (C-8), 25.30 (C13), 27.60 (C-7), 28.60 (C-14), 30.90 (C-3), 35.40 (C-2), 40.70 (C-5), 41.20 (C-8a), 49.20 (C-1), 50.90 (C-10), 75.50 (C-6), 119.10 (C-4), 141.70 (C-4a), 176.50 (C-9); m/z 266 $\left(\mathrm{M}^{+}, 5 \%\right), 248$ (12), 233 (1), 216 (1), 207 (100), 206 (11), 189 (97), 188 (11), 173 (35), 163 (19), 147 (26), 145 (12), 135 (38), 134 (8), 133 (33), 121 (31), 120 (13), 119 (65), 115 (11), 107 (42), 105 (41), 93 (32), 91 (46), 79 (28), 77 (26), 55 (37), 43 (59) and 41 (62).

Octalin ( \pm )-13. IR $v_{\max } / \mathrm{cm}^{-1} 3454,3047,2988,2878$, 1726, 1458, 1380, 1257, 1202, 1109, 1082, 1028, 981 (film); ${ }^{1} \mathrm{H}$ NMR $\left(300 \mathrm{MHz}, \mathrm{CDCl}_{3}\right) \delta 0.91$ (d, J 6.2 Hz, 3H, H-12), 1.08 (s, 3H, H-14), 1.10 (s, 3H, H-11), 1.11 (s, 3H, H-13), 1.20 (m, 1H, H-8), 1.54 (ddd, $J 13$ and 4 Hz, 1H, H-8), 1.60 (br, s, 1H, OH), 1.70 (m, 2H, H-3 and H-7), 1.88 (ddd, $J 12$ and $4 \mathrm{~Hz}, 1 \mathrm{H}, \mathrm{H}-7), 2.12(\mathrm{~m}, 1 \mathrm{H}, \mathrm{H}-3), 2.16(\mathrm{~m}, 1 \mathrm{H}, \mathrm{H}-2)$, 2.22 (dm, J 13 Hz, 1H, H-8a), 3.43 (br, s, 1H, H-6), 3.68 (s, $3 \mathrm{H}, \mathrm{H}-10), 5.45$ (m, 1H, H-4); ${ }^{13} \mathrm{C} \mathrm{NMR}\left(75.46 \mathrm{MHz}, \mathrm{CDCl}_{3}\right)$ $\delta 16.25$ (C-11), 17.08 (C-12), 24.49 (C-14), 25.60 (C-13), 26.00 (C-8), 28.16 (C-2), 29.12 (C-7), 31.43 (C-3), 42.32 (C-5), 43.37 (C-8a), 48.71 (C-1), 51.19 (C-10), 76.36 (C6), 120.00 (C-4), 140.80 (C-4a), 176.85 (C-9); m/z $266\left(\mathrm{M}^{+}\right.$, 1\%), 248 (4), 233 (0.5), 216 (16), 207 (1), 206 (1), 189 (36), 188 (18), 173 (35), 163 (5), 147 (11), 145 (11), 135 (9), 134 (6), 133 (15), 121 (22), 120 (30), 119 (100), 115 (21), 107 (33), 105 (26), 93 (22), 91 (32), 79 (20), 77 (17), 55 (31), 43 (36) and 41 (46).

Octalin (士)-14. Mp 72-73 ${ }^{\circ} \mathrm{C}$; IR $v_{\max } / \mathrm{cm}^{-1} 3405,3049$, 2961, 2875, 1726, 1457, 1384, 1361, 1260, 1239, 1195, 1118, 1104, 1052, 1009 (film); ${ }^{1} \mathrm{H}$ NMR (300 MHz, $\left.\mathrm{CDCl}_{3}\right) \delta 0.78(\mathrm{~d}, J 6.5 \mathrm{~Hz}, 3 \mathrm{H}, \mathrm{H}-12), 0.89$ (s, 3H, H-11), 0.99 (s, 3H, H-13), 1.16 (s, 3H, H-14), 1.27 (qd, J 15, 13 and $4 \mathrm{~Hz}, 1 \mathrm{H}, \mathrm{H}-8$ ), 1.40 (ddd, $J 15,13$ and $4 \mathrm{~Hz}, 1 \mathrm{H}, \mathrm{H}-$ 8), 1.57 (ddd, $J 15,13$ and $4 \mathrm{~Hz}, 1 \mathrm{H}, \mathrm{H}-7), 1.78$ (m, 2H, $\mathrm{H}-3$ and H-7), 1.95 (m, 2H, H-2 and H-3), 2.72 (dm, $J 13$ Hz, 1H, H-8a), 3.24 (dd, $J 13$ and 4 Hz, 1H, H-6), 3.70 (s, $3 \mathrm{H}, \mathrm{H}-10), 5.59$ (m, 1H, H-4); ${ }^{13} \mathrm{C}$ NMR (75.46 MHz, $\left.\mathrm{CDCl}_{3}\right) \delta 9.67$ (C-11), 16.24 (C-12), 21.70 (C-13), 24.26 (C-14), 25.46 (C-8), 29.87 (C-7), 30.86 (C-3), 35.57 (C2), 41.60 (C-8a), 41.79 (C-5), 49.62 (C-1), 51.72 (C-10), 76.54 (C-6), 118.32 (C-4), 143.95 (C-4a), 178.42 (C-9); m/z $266\left(\mathrm{M}^{+}, 1 \%\right), 248$ (13), 233 (3), 216 (2), 207 (4), 206 (11), 190 (15), 189 (100), 188 (20), 173 (81), 163 (5), 147 (18), 145 (15), 135 (9), 134 (6), 133 (27), 121 (17), 
120 (15), 119 (76), 115 (11), 107 (25), 105 (36), 93 (25), 91 (42), 79 (24), 77 (26), 55 (37), 43 (51) and 41(63).

Octalin ( \pm )-15. Mp 69-70 ${ }^{\circ} \mathrm{C}$; IR $v_{\max } / \mathrm{cm}^{-1} 3531,3355$, 3287, 3054, 2970, 2837, 1728, 1712, 1664, 1455, 1435, 1380, 1357, 1263, 1216, 1112, 1084, 1055, 1018 (film); ${ }^{1} \mathrm{H}$ NMR $\left(300 \mathrm{MHz}, \mathrm{CDCl}_{3}\right) \delta 0.89(\mathrm{~d}, J 6.2 \mathrm{~Hz}, 3 \mathrm{H}, \mathrm{H}-$ 12), 0.97 (s, 3H, H-13), 1.07 (s, 3H, H-11), 1.12 (s, 3H, H14), 1.28 (m, 2H, H-8), 1.52 (ddd, $J$ 19, 12 and $4 \mathrm{~Hz}, 1 \mathrm{H}$, H-7), 1.68 (dddd, $J$ 19, 12, 4 and $2 \mathrm{~Hz}, 1 \mathrm{H}, \mathrm{H}-3$ ), 1.82 (dd, $J 12$ and $4 \mathrm{~Hz}, 1 \mathrm{H}, \mathrm{H}-7), 2.05$ (m, 1H, H-3), 2.08 (m, 1H, H-8a), 2.13 (m, 1H, H-2), 3.16 (dd, $J 12$ and $4 \mathrm{~Hz}, 1 \mathrm{H}, \mathrm{H}-$ 6), 3.68 (s, 3H, H-10), $5.43(\mathrm{~m}, 1 \mathrm{H}, \mathrm{H}-4) ;{ }^{13} \mathrm{C}$ NMR (75.46 MHz, $\left.\mathrm{CDCl}_{3}\right) \delta 15.95$ (C-11), 17.17 (C-12), 18.76 (C-13), 24.76 (C-14), 27.67 (C-2), 28.98 (C-8), 31.20 (C7), 31.47 (C-3), 42.25 (C-5), 43.58 (C-8a), 48.54 (C-1), 51.18 (C-10), 78.38 (C-6), 117.38 (C-4), 143.24 (C-4a), $177.00(\mathrm{C}-9) ; \mathrm{m} / z 266\left(\mathrm{M}^{+}, 1 \%\right), 248$ (16), 233 (3), 216 (3), 207 (4), 206 (4), 145 (14), 135 (13), 134 (9), 133 (23), 121 (22), 120 (17), 119 (76), 115 (17), 107 (42), 105 (34), 93 (30), 91 (44), 79 (28), 77 (25), 55 (39), 43 (50) and 41 (62).

$\left(1 S^{*}, 2 S^{*}\right)$-1-Methoxycarbonyl-6-oxo-1,2,5,5-tetramethyl$1,2,3,4,5,6,7,8$-octahydronaphthalene $( \pm)-(18)$ and $\left(1 R^{*}, 2 S^{*}, 8 a R^{*}\right)$-2-methoxycarbonyl-6-oxo-1,2,5,5tetramethyl-1,2,3,5,6,7,8,8a-octahydronaphthalene ( \pm )(19)

A mixture of methyl angelate $(0.5 \mathrm{~mL})$ and vinylcyclohexene $7 \mathbf{b}$ (20.00 mg, $134 \mathrm{mmol})$, was sealed in a glass ampoule which was introduced in an explosion protecting stainless steel tube device at $170{ }^{\circ} \mathrm{C}$ for 7 days. Before opening, the ampoule was refrigerated and the remaining methyl angelate was removed in vacuo using a kugelrohr apparatus. The residue was purified by flash chromatography on silica gel eluted with hexane/ethyl acetate $95: 5(\mathrm{v} / \mathrm{v})$ furnishing $10 \mathrm{mg}$ of $( \pm)-\mathbf{1 8}$ and $16 \mathrm{mg}$ of a $\sim 1: 1$ mixture of $( \pm)-\mathbf{1 8}$ and $( \pm)-\mathbf{1 9}$.

Octalin ( \pm )-18. IR $v_{\max } / \mathrm{cm}^{-1} 2970,2934,2882,1722$, 1463, 1381, 1229, 1194, 1158, 1118, 977, 748 (film); ${ }^{1} \mathrm{H}$ NMR (300 MHz, CDCl $) \delta 0.90$ (s, 3H, H-12), 1.13 (s, $3 \mathrm{H}, \mathrm{H}-11 *), 1.23$ (s, 3H, H-13*), 1.27 (s, 3H, H-14*), 1.57 (m, 1H, H-2), 1.65 (m, 2H, H-3), 2.10 (m, 1H, H-3'), 2.18 (m, 2H, H-8), 2.29 (m, 1H, H-7'), 2.31 (m, 1H, H-3”), 2.61 (m, 1H, H-7"), 3.67 (s, 3H, OMe); ${ }^{13} \mathrm{C}$ NMR (75.45 $\left.\mathrm{MHz}, \mathrm{CDCl}_{3}\right) \delta$ see Scheme 4; $\mathrm{m} / \mathrm{z} 264\left(\mathrm{M}^{+}, 56 \%\right), 249$ (4), 221 (13), 206 (13), 205 (100), 204 (11), 189 (17), 187 (19), 163 (61), 161 (26), 147 (13), 135 (11), 121 (24), 119 920), 107 921), 105 (17), 91 (20), 77 (11) and 55 (11); HRMS $\left(\mathrm{M}^{+}\right)$. Found: 264.17250. Calcd for $\mathrm{C}_{16} \mathrm{H}_{24} \mathrm{O}_{3}$ : 264.17254. * Interchangeable.
Octalin ( \pm )-19. ${ }^{~} \mathrm{H}$ NMR $\left(300 \mathrm{MHz}, \mathrm{CDCl}_{3}\right) \delta 0.88(\mathrm{~d}$, $J 7 \mathrm{~Hz}, \mathrm{H}-12$ ), 3.10 (dm, $J 10 \mathrm{~Hz}, 1 \mathrm{H}, \mathrm{H}-8 \mathrm{a}), 3.70$ (s, OMe), $5.52(\mathrm{~m}, 1 \mathrm{H},) ;{ }^{13} \mathrm{C} \mathrm{NMR}\left(75.45 \mathrm{MHz}, \mathrm{CDCl}_{3}\right) \delta$ see Scheme 4; $\mathrm{m} / \mathrm{z} 264\left(\mathrm{M}^{+}, 4 \%\right), 249\left(\mathrm{M}^{+}\right.$- $\left.\mathrm{Me}, 1\right), 205$ (21), 189 (12), 172 (22), 149 (12), 133 (19), 121 (29), 119 (35), 107 (47), 105 (37), 93 (30), 91 (51), 79 (33), 77 (33), 67 (23), 59 (25), 55 (54), 43 (53) and 41 (100).

$\left(1 S^{*}, 2 S^{*}, 8 a R^{*}\right)-1$-Methoxycarbonyl-1,2,5,5-tetramethyl1,2,3,5,6,7,8,8a-octahydronaphthalene ( \pm )-(22) and $\left(1 S^{*}, 2 R^{*}, 8 a S^{*}\right)$-2-methoxycarbonyl-1,2,5,5-tetramethyl1,2,3,5,6,7,8,8a-octahydronaphthalene ( \pm )-(23)

A mixture of methyl angelate $(1.5 \mathrm{~mL})$ and vinylcyclohexene $7 \mathrm{c}(355.0 \mathrm{mg}, 2.6 \mathrm{mmol})$, was sealed in a glass ampoule which was introduced in an explosion protecting stainless steel tube device at $170{ }^{\circ} \mathrm{C}$ for 7 days. Before opening, the ampoule was refrigerated and the remaining methyl angelate was removed in vacuo using a kugelrohr apparatus. The residue was purified by flash chromatography on silica gel eluted with hexane/ethyl acetate $8: 1$ (v/v), furnishing $424.0 \mathrm{mg}$ (65\% yield) of a $\sim 2: 1$ mixture of $( \pm)$-22 and ( \pm )-23. A sample of the mixture was separated by silica gel $10 \% \mathrm{AgNO}_{3}(\mathrm{w} / \mathrm{w})$ preparative TLC furnishing $( \pm)-22$ with less than $20 \%$ of $( \pm)-\mathbf{2 3}$ which allowed the spectroscopic analysis of both compounds.

Octalin ( \pm )-22. ${ }^{1} \mathrm{H}$ NMR $\left(300 \mathrm{MHz}, \mathrm{CDCl}_{3}\right) \delta 0.90(\mathrm{~d}$, $J 7 \mathrm{~Hz}, 3 \mathrm{H}, \mathrm{H}-12), 0.95$ (m, 1H, H-8'), 1.01 (s, 3H, H-14), 1.10 (s, 3H, H-13), 1.25 (s, 3H, H-11), 1.26 (m, 1H, H-6'), 1.41 (dm, $J 13 \mathrm{~Hz}, 1 \mathrm{H}, \mathrm{H}-6$ "), $1.54-1.61$ (m, 3H, H-7 and H-2), 1.84 (m, 1H, H-8”), 1.95 (dm, J $16 \mathrm{~Hz}, 1 \mathrm{H}, \mathrm{H}-3^{\prime}$ ), 2.08 (m, 1H, H-8), 2.13 (m, 1H, H-3"), 3.62 (s, 3H, OMe), $5.52(\mathrm{~m}, 1 \mathrm{H}, \mathrm{H}-4) ;{ }^{13} \mathrm{C}$ NMR $\left(75,45 \mathrm{MHz}, \mathrm{CDCl}_{3}\right) \delta$ see Figure 4; $m / z 250\left(\mathrm{M}^{+}, 15 \%\right), 235$ (2), 218 (7), 191(71), 190 (100), 175 (78), 161 (7), 147 (25), 135 (23), 133 (24), 121 (53), 120 (41), 119 (64), 115 (17), 109 (25), 105 (74), 95 (24), 93 (38), 91 (61), 80 (48), 77 (34), 69 (25), 67 (26), 65 (17), 59 (33), 55 (48), 43 (33) and 41 (87).

Octalin ( \pm )-23. ${ }^{1} \mathrm{H}$ NMR $\left(300 \mathrm{MHz}, \mathrm{CDCl}_{3}\right) \delta 0.80(\mathrm{~d}, J$ $7 \mathrm{~Hz}, 3 \mathrm{H}, \mathrm{H}-12), 1.04$ (m, 1H, H-8'), 1.06 (s, 3H, H-14), 1.07 (s, 3H, H-13), 1.10 (s, 3H, H-11), 1.23 (m, 1H, H-6'), 1.44 (m, 1H, H-6"), 1.57 (m, 2H, H-7), 1.70 (m, 1H, H-3'), 1.73 (m, 1H, H-8 “), 1.86 (m, 1H, H-1), 2.33 (dm, J 17.6 Hz, 1H, H-3"), 2.77 (dm, J 13 Hz, 1H, H-8a), 3.67 (s, 3H, OMe), 5.33 (m, 1H, H-4); ${ }^{13} \mathrm{C}$ NMR (75,45 MHz, $\left.\mathrm{CDCl}_{3}\right) \delta$ 15.86 (C-12), 20.19 (C-11), 22.24 (C-7), 27.89 (C-14), 29.00 (C-8), 29.41 (C-3), 29.57 (C-13), 35.22 (C-1), 35.22 (C8a), 36.25 (C-5), 41.23 (C-6), 47.76 (C-2), 51.47 (OMe), 112.99 (C-4), 144.89 (C-4a), 177.94 (C-15); m/z $250\left(\mathrm{M}^{+}\right.$, 14\%), 235 (3), 218 (4), 191(100), 190 (81), 175 (66), 147 (18), 135 (25), 133 (15), 121 (51), 120 (26), 119 (44), 109 
(24), 105 (44), 95 (23), 93 (25), 91 (35), 80 (37), 77 (16), 69

(16), 67 (14), 65 (8), 55 (21), 43 (16) and 41 (32).

$\left(1 R^{*}, 2 S^{*}, 8 a R^{*}\right)$-1-Methoxycarbonyl-1,2,5,5-tetramethyl1,2,3,5,6,7,8,8a-octahydronaphthalene ( \pm -(24) and $\left(1 S^{*}, 2 R^{*}, 8 a S^{*}\right)$-1-methoxycarbonyl-1,2,5,5-tetramethyl$1,2,3,5,6,7,8,8$ a-octahydronaphthalene $( \pm)-(25)$

A mixture of methyl tiglate $(0.5 \mathrm{~mL})$ and vinylcyclohexene $7 \mathbf{c}(15.00 \mathrm{mg}, 0.11 \mathrm{mmol})$, was sealed in a glass ampoule which was introduced in an explosion protecting stainless steel tube device at $170{ }^{\circ} \mathrm{C}$ for 7 days. Before opening, the ampoule was refrigerated and the remaining methyl angelate was removed in vacuo using a kugelrohr apparatus. The residue was purified by flash chromatography on silica gel eluted with hexane/ethyl acetate $8: 1$ $(\mathrm{v} / \mathrm{v})$, furnishing $18 \mathrm{mg}$ of a 3:2 mixture of adducts $( \pm)-\mathbf{2 4}$ and $( \pm)-\mathbf{2 5}$.

Octalin ( \pm )-24. ${ }^{1} \mathrm{H}$ NMR $\left(500 \mathrm{MHz}, \mathrm{CDCl}_{3}\right) \delta 0.77(\mathrm{~d}$, $J 7 \mathrm{~Hz}, 3 \mathrm{H}, \mathrm{H}-12), 0.91$ (s, 3H, H-11), 1.03 (s, 3H, H-14), 1.08 (s, 3H, H-13), 1.15 (m, 1H, H-8'), $1.20(\mathrm{~m}, 1 \mathrm{H}, \mathrm{H}-$ 6'), 1.39 (m, 2H, H-8"and H-6"), 1.54 (m, 2H, H-7), 1.74 (m, 1H, H-3"), 1.91 (m, 1H, H-3"), 1.95 (m, 1H, H-2), $2.73(\mathrm{dm}, J 13 \mathrm{~Hz}, 1 \mathrm{H}, \mathrm{H}-8 \mathrm{a}), 3.69$ (s, 3H, OMe), 5.46 (m, $1 \mathrm{H}, \mathrm{H}-4) ;{ }^{13} \mathrm{C}$ NMR $\left(125.7 \mathrm{MHz}, \mathrm{CDCl}_{3}\right) \delta$ see Figure 4.

Octalin ( \pm )-25. ${ }^{1} \mathrm{H}$ NMR $\left(500 \mathrm{MHz}, \mathrm{CDCl}_{3}\right) \delta 0.89(\mathrm{~d}$, $J 6.4 \mathrm{~Hz}, 3 \mathrm{H}, \mathrm{H}-12), 1.02$ (s, 3H, H-14), 1.04 (s, 3H, H13), 1.06 (s, 3H, H-11), 1.16 (m, 1H, H-6'), 1.24 (m, 1H, H-8'), 1.32 (m, 1H, H-8"), 1.45 (dm, J $13 \mathrm{~Hz}, 1 \mathrm{H}, \mathrm{H}-6$ "), 1.58 (m, 2H, H-7), 1.64 (m, 1H, H-3'), 2.06 (dd, $J 11$ and $6 \mathrm{~Hz}, 1 \mathrm{H}, \mathrm{H}-3$ "), 2.11 (m, 1H, H-2), $2.13(\mathrm{dm}, J 12 \mathrm{~Hz}$, 1H, H-8a), 3.67 (s, 3H, OMe), 5.31 (m, 1H, H-4); ${ }^{13} \mathrm{C} \mathrm{NMR}$ $\left(125.7 \mathrm{MHz}, \mathrm{CDCl}_{3}\right) \delta$ see Figure 4 .

\section{Acknowledgements}

The authors are indebted to FAPESP for financial support. GJAC is indebted do CNPq for a scholarship and DSM is indebted to UFU for his leave of absence in order to work on his $\mathrm{PhD}$ thesis.

\section{Supplementary Material}

Crystallographic data (excluding structure factors) for the structures of compounds \pm 12 and \pm 15 have been deposited with the Cambridge Crystallographic Data Centre as supplementary publication nos. CCDC 1267-659 and CCDC 1267-660. Copies of the data can be obtained, free of charge, on application to CCDC, 12 Union Road, Cambridge CB2 1EZ, UK, (fax: +44 1223336033 or email: deposit@ccdc.cam.ac.uk).

\section{References}

1. Leboeuf, M.; Hamonnière, M.; Cavè, A.; Gottlieb, H. E.; Kunesch, N.; Wenkert, E. Tetrahedron Lett. 1976, 3559.

2. Swersey, J. C.; Barrows, L. R.; Ireland, C. M. Tetrahedron Lett. 1991, 32, 6687.

3. Gunasekera, S. P.; McCarthy, P.; Kelly-Borges, M.; Lobkovsky, E.; Clardy, J. J. Am. Chem. Soc. 1996, $118,8759$.

4. Pinto, A. C.; Antunes, O. A. C.; Rezende, C. M.; Correia, C. R. D. Phytochemistry 1995, 38, 1269.

5. Teresa, J. P.; Urones, J. G.; Marcos, I. S.; Bermejo, F.; Basabe, P. Phytochemistry 1983, 22, 2783.

6. Yoon, T.; Gala, S.; Danishefsky, S. J. Angew, Chem., Int. Ed. Engl. 1994, 33, 853.

7. (a) Boukouvalas, J.; Cheng, Y. X.; Robichaud, J. J. Org. Chem. 1998, 63, 228; (b) Magnuson, S. R.; SeppLorenzino, L.; Rosen, N.; Danishefsky, S. J. J. Am. Chem. Soc. 1998, 120, 1615; (c) Miyaoka, H.; Kajiwara, Y.; Yamada, Y. Tetrahedron Lett. 2000, 41, 911; (d) Takahashi, M.; Dodo, K.; Hashimoto, Y.; Shirai, R. Ibid. 2000, 41, 2111.

8. Kakisawa, H.; Ikeda, M. Nippon Kagaku Zasshi 1967, 88, 476 In: Chem. Abstr. 1968, 69, 2740q.

9. Hollinshead, D. M.; Howell, S. C.; Ley, S. V.; Mahon, M.; Ratcliffe, N. M.; Worthington, P. A. J. Chem. Soc., Perkin Trans. 1 1983, 1579.

10. Mori, K.; Watanabe, N. Tetrahedron 1986, 42, 273.

11. Knapp, S.; Sharma, S. J. Org. Chem. 1985, 50, 4996.

12. (a) Crispin, D. J.; Vanstone, A. E.; Whitehurst, J. S. J. Chem. Soc. (C) 1970, 10; (b) Mori, K.; Mori, H. Org. Synth. 1989, 68, 56.

13. (a) Imamoto, T.; Sugiura, Y.; Takiyama, N. Tetrahedron Lett. 1984, 25, 4233; (b) Imamoto, T.; Takiyama, N.; Nakamura, K. Tetrahedron Lett. 1985, 26, 4763; (c) Imamoto, T.; Takiyama, N.; Nakamura, K.; Hatajima, T.; Kamiya, Y. J. Am. Chem. Soc. 1989, 111, 4392; (d) Imamoto, T. Organocerium reagents In: Trost, B. M.; Fleming, I.; Schreiber, S. L. Comprehensive organic synthesis. London, Pergamon Press, 1991. p231-250. v1.

14. Nishiguchi, T.; Machida, N.; Yamamoto, E. Tetrahedron Lett. 1987, 28, 4565.

15. (a) Lee, J.; Snyder, J. K. J. Org. Chem. 1990, 55, 4995; (b) Haiza, M.; Lee, J.; Snyder, J. K. ibid. 1990, 55, 5008.

16. (a) Stang, P. J.; Duebner, T. E. Org. Synth., Collect. 1974, 54, 79; (b) Stang, P. J.; Fisk, T. E. Synthesis 1979, 438; (c) Stang, P. J.; Treptow, W. Synthesis 1980, 283; (d) Stang, P. J.; Hanack, M.; Subramanian, L. R. Synthesis 1982, 85. 
17. Hendrickson, J. B.; Bergeron, R. Tetrahedron Lett. 1973, 4607.

18. Scott, W. J.; Stille, J. K. J. Am. Chem. Soc. 1986, 108, 3033; (b) Stille, J. K.; Groh, B. L. Ibid. 1987, 109, 813.

19. Prepared as previously reported: Seyferth, D.; Stone, F. G. A. J. Am. Chem. Soc. 1957, 79, 515.

20. Prepared as previously reported: Buckles, R. E.; Mock, G. V. J. Org. Chem. 1950, 15, 680.

21. The DA reaction between $\mathbf{7 b}$ and methyl tiglate furnished two diastereomers, in a 1:1 ratio. Chemical shifts of carbon- 8 a of both compounds ( $\delta 42.2$ and 43.4) was taken as diagnostic to assign the regioselectivity of the reaction $(\mathrm{C}-8 \mathrm{a}$ chemical shifts about $\delta 41-45$, when linked to a quaternary C-1 and about $\delta 35$ when connected to a tertiary $\mathrm{C}-1$ ). Therefore the reaction was highly regioselective but no stereoselectivity was observed.

22. Lu, Y. C.; Barth, G.; Kieslich, K.; Strong, P. D.; Duax, W. L.; Djerassi, C. J. Org. Chem. 1983, 48, 4549.

23. Mori, K.; Mori, H. Org. Synth. 68, 56, 1989.

Received: November 14, 2000

Published on the web: May 16, 2001

FAPESP helped in meeting the publication costs of this article. 